\title{
Assessing Socio-Cultural Factors Affecting in Protection of Forests (Case study: Sari, Iran)
}

\author{
Mohammad Abedi \\ Department of Agricultural Management, Qaemshahr Branch, \\ Islamic Azad University, Qaemshahr, Iran \\ E-mail: abedi114@yahoo.com
}

\section{Doi:10.5901/mjss.2013.v4n10p789}

\begin{abstract}
The purpose of this study was to determine the perceptions of forestry and rang department specialists in Sari Township regarding effective factors in protection of forests. The population of this study included 230 forest specialists in Sari Township. A stratified random sample of 140 specialists was selected. The research design used for this study utilized descriptive survey research methodology. A questionnaire was developed to assess the effective factors in protection of forests. Major conclusions were that An adequate number of protection personnel are needed that protect forests; that Also should be provided vehicles for protection personnel; that Monitoring on the cooperatives and other company which practice in ground of forest is also necessary and important in forest protection and conservation. Therefore necessary that we work on the effective factors that impact on the protection of forests.
\end{abstract}

\section{Introduction}

There are an estimated 3870 million hectares of forest worldwide, of which almost 95 percent are natural forest and 5 percent are forest plantations also forest cover about 30 percent of the earth's land area(FAO, 2001).

Tropical deforestation and degradation of forests in many parts of the world are negatively affecting the availability of forest goods and services. While forest area in developed countries has stabilized and is slightly increasing overall, deforestation has continued in developing countries. The estimated net annual change in forest area worldwide during the past decade was -9.4 million hectares; representing the difference between the estimated annual rates of deforestation of 14.6 million hectares and the estimated annual rate of forest area increase of 5.2 million hectares(FAO, 2001).

The causes of forest degradation are varied. Some, such as overexploitation of forest products, can be avoided or minimized by sound forest planning and management, whereas the effects of others, such as natural disasters, can be mitigated by contingency planning. Factors responsible for this loss are the conversion of forestland to produce food for a burgeoning world population, especially in developing countries (FAO, 1993; Swanson, 1997), as well as logging for timber and fuel. These are legitimate human needs and uses of forestland. But, lack of knowledge, and legal and social systems often encourage excessive, non-sustainable land clearing resulting in long-term adverse social and environmental impacts (Jones, 1987).

The forestry situation in Iran is no different than other vulnerable areas in the world. There are an estimated 12 millions hectares of forest in Iran, while there are 18 millions hectares forest in 1950. At present only \%11 of this forests are commercial. Statistics show that in one year decrease about 12245 hectares forest in Iran (Anonymous, 2001).

This forest threatened by unsound forest management activities including inappropriate productivity (too much) by government companies private sector and cooperative, intensive agricultural operations, indiscriminate forest activities and timber use, Lack of vehicles for foresters, Smuggling of wood, Lack of near cooperation between forest sector with judicial and disciplinary power, Lack of adequate protection personnel, Changing forestlands to agricultural fields, Presence of livestock in forests, Continuous changes in policies, legislation and programs, Lack of education level among personnel, Threat of pests and diseases to plantations, Making roads inside forests, Lack of participation by forest dwellers in protection of forests, Lack of politicians serious belief on the protection of forest, cutting trees by forest dwellers, changing forestlands to agricultural fields, happening of fire and other factors (Anonymous, 1996; Khosrowshahi and Ghavamie, 1994; Farhadian, 1998; Abedi, 2002). 
The forest and Range Organization (FRO) of Iran and its Research Institute are responsible for the management of forests. An office of extension and training was established in the FRO in 1990 to educate and work with these managers and with target audiences of forest landowners and forest dwellers in supporting and participating in forestry. Farhadian(1998) studied the FRO's mission and recommended that a strong linkage should be forget between the Office of Extension and Training and the Research Institute. He emphasized that a key responsibility of managers and stuff of the FRO was providing for the participation of people of the planning and implementation of forestry development.

According FAO (1993), most forests in the developing world are on land on which indigenous groups and rural communities depend for their livelihood. Therefore, it is essential that they be involved in forest management programs. In a similar vein, Sharma (1992) emphasized that attitude of people influence how they manage and use forests. In a Report of the Islamic Republic of Iran on Forestry Development and Key Events presented to the Twelfth Session of the Near East Forestry Commission, it was stated that while forests in different regions of the country important, those of the Caspian Sea Region (Mazandaran and Gilan provinces) are the only economically productive forests in Iran. Mazandaran provinces include Sari and noshahr Township. Sari Township has important role in Iran economic that produces 50\% forest products of Iran. There are a estimated 643793 hectares of forest in Sari Township and there are 1186145 forest dwellers and 1628700 livestock in this region. Considering this situation, a study of forestry and range department specialists in Sari Township was considered worthwhile (Anonymous, 2002).

\section{Purpose of the paper}

The purpose of this study was to determine the perceptions of forestry and rang department specialists in Sari Township regarding effective factors in protection of forests. Specific objective of the study were to:

1. Determine factors perceived by forestry and range department specialists to be effective in Protection of forest.

2. Determine factors perceived by forestry and range department specialists that contribute deforestation.

\section{Population}

The population of this study included 230 forest specialists in Sari Township. A stratified random sample of 140 specialists was selected.

\section{Research Design and Data Analysis}

The research design used for this study utilized descriptive survey research methodology. A questionnaire was developed to assess the effective factors in protection of forests. The questionnaire covered two areas: This areas including effective factors in protection of forests, effective factors in deforestation of forests. In this two areas a 5-point likert-type scale was used to assess expert's self-perceived knowledge. Content and face validity was determined by faculty and graduate students in the department of agricultural extension and education at Tarbiat Modarres University. The instrument was pilot tested with 10 forestry specialists in the forestry and range organization under ministry of agriculture two weeks prior to the study, and needed modifications were made. cronbach's alpha reliability coefficients for sections $1-3$ of the instrument ranged 0.72 to 0.93 .

\section{Results}

\section{Objective1}

Table 1 shoes the rank important of 21 factors that are effective in Protection of forest as perceived by specialists. The top three factors that were effective in protection of forests were: near cooperation between forest sector with judicial and disciplinary power, promoting technical knowledge of foresters and improving incomplete laws. Delegation the responsibility of forest protection and preservation to cooperatives, Delegation the responsibility of forest protection and preservation to private sector and implementation of forestry project by the government were considered to be the least important factors. 
Table1: Rank of factors effective in protection of forests as perceived by specialists

\begin{tabular}{|c|c|c|c|}
\hline Rank & Factor & Mean & SD \\
\hline 1 & Near cooperation between forest sector with judicial and disciplinary power & 4.51 & 0.66 \\
\hline 2 & promoting technical knowledge of forest dwellers & 4.50 & 0.65 \\
\hline 3 & Improving incomplete laws & 4.31 & 0.97 \\
\hline 4 & Exit of livestock from forests & 4.18 & 0.96 \\
\hline 5 & Controlling factories that relate to wood & 4.10 & 0.97 \\
\hline 6 & Resting protection of natural resource as important element in huge programming & 4.10 & 1.14 \\
\hline 7 & Careful implementation of lows that is connected to aggression punishment & 4.09 & 1.20 \\
\hline 8 & Establishing special court of justice about aggression of forest & 4.07 & 1.16 \\
\hline 9 & Approving necessary laws & 4.06 & 1.04 \\
\hline 10 & Establishing armed units for protection of forest & 4.03 & 1.08 \\
\hline 11 & Delegating authority about assessing wood factories from province judicial power to city & 4.01 & 1.96 \\
\hline 12 & Using of disciplinary power & 3.88 & 1.12 \\
\hline 13 & $\begin{array}{l}\text { Delegating authority to personnel that work in forestry and range organization/township about } \\
\text { assessing wood factories }\end{array}$ & 3.86 & 1.30 \\
\hline 14 & Establishing air control network & 3.85 & 1.13 \\
\hline 15 & Establishing special staff for extinguishing of fire & 3.83 & 1.20 \\
\hline 16 & Diffusion of information on natural resource benefits to youth, especially students & 3.80 & 1.08 \\
\hline 17 & Determining appropriate limit for wood factories & 3.12 & 1.14 \\
\hline 18 & Adoption of plans with forest dwellers needs & 3.07 & 1.13 \\
\hline 19 & Establishing productivity factories by using forest inputs in creating jobs & 3.01 & 1.24 \\
\hline 20 & Delegation the responsibility of forest protection and preservation to private sector & 2.95 & 1.16 \\
\hline 21 & Delegation the responsibility of forest protection and preservation to cooperatives & 2.94 & 1.19 \\
\hline
\end{tabular}

likert-type scale: $1=$ absolutely opposite $\quad 2=$ opposite $\quad 3=$ rather agree $\quad 4=$ agree $\quad 5=$ absolutely agree

\section{Objective 2}

Table 2 shoes the rank important of 13 factors that important contributors to deforestation as perceived by specialists. The top tree factors that important contributors to deforestation were lack of vehicles for foresters, inappropriate productivity (too much) from forest by cooperatives and struggling of wood. Happening of flood, lack of careful programming for productivity of forests and lack of politician's serious belief on the protection of forests were considered to be the least important factors.

Table 2: Rank of factors contributing to deforestation as perceived by specialists

\begin{tabular}{llll}
\hline Rank & Factors & Mean & SD \\
\hline 1 & Lack of vehicles for foresters & 4.06 & 1.00 \\
2 & Inappropriate productivity (too much) from forest by cooperatives & 4.02 & 1.03 \\
3 & Smuggling of wood & 4.01 & 1.09 \\
4 & Lack of near cooperation between forest sector with judicial and disciplinary power & 3.92 & 1.16 \\
5 & Lack of mobilizing forestry departments to firefighting stations & 3.30 & 1.05 \\
6 & Lack of special army units for protection of forests & 3.30 & 1.14 \\
7 & Lack of participation by forest dwellers in protection of forests & 3.29 & 1.03 \\
8 & Lack of understanding of the value of forest among people & 3.27 & 1.19 \\
9 & Inappropriate productivity (too much) from forest by government companies & 3.27 & 1.30 \\
10 & Population increase and the need for more productivity from forests & 3.26 & 1.17 \\
11 & Lack of politicians serious belief on the protection of forest & 3.20 & 1.19 \\
12 & Lack of careful programming for productivity of forests & 3.17 & 1.18 \\
13 & Happening of flood & 3.15 & 1.09 \\
\hline
\end{tabular}

likert-type scale: $1=$ absolutely opposite $\quad 2=$ opposite $\quad 3=$ rather agree $\quad 4=$ agree $\quad 5=$ absolutely agree 


\section{Conclusion}

An adequate number of protection personnel are needed that protect forests. Also should be provided vehicles for protection personnel. This conclusion is supported by the finding that specialists viewed lack of vehicle foresters and lack of adequate protection personnel. Assessing human power is Sari Township showed that there are in lieu of 3000 hectares just one forest specialist? Also there are in this region about 363 protection personnel which this amount contain $29 \%$ total of specialists in sari. region in other words there are in lieu of 1770 hectares forests just one protection personnel (reporting of )

Monitoring on the cooperatives and other company which practice in ground of forest is also necessary and important in forest protection and conservation. This conclusion is supported by the finding that specialist felt that an effective factor which contributes deforestation of forests is to inappropriate productivity (too much) from forest by cooperatives.

Legal and organizational considerations are impacting forest protection and conservation. This conclusion is supported by the finding that specialists perceived that making foresters live in the forest area, and lack of near cooperation between forest sector with judicial and disciplinary power would be effective measures in protecting forests.

\section{References}

Anonymous (2002). Report of the state of forests in sari's region. Forestry and Range Department of Sari Township.

Anonymous (2001). Report of the state of forests in Iran. Forestry and Range Organization of Iran.

Anonymous (1996). Report of the Islamic Republic of Iran on Forestry Development and Key Events. Presented to the Twelfth Session of the Near East Forestry Commission. October. 27, 3-4

Abedi, M. (1998). Assessing Effective Factors in Protection of Sari Township Forests. Master's thesis, Tarbiat Modarres University, Tehran, Iran.

FAO (1993). The challenge of sustainable forest management: What future for the world's forests. Rome: FAO.

FAO (2001). The state of world forests in 2000. Rome: FAO.

Farhadian, H. (1998). The role of extension education in protection of forests. Master's thesis, Tarbiat Modarres University, Tehran, Iran.

Jones, R, K. (1987). Arid and semiarid rangelands: Guidelines for development. Morrilton, AR:Winrock International.

Khosrowshahi, M. and Ghavamie, S. (1994). Be aware. Office of Extension Education, Forest and Range Organization of Iran, Second edition.

Sharma, p. S. (1992). Managing the world's forests: Looking for balance between conservation and development. Dubuque, IA: Kendall/Hunt publishing company.

Swanson, B.E. (Ed.). (1997). Improving agricultural extension: A reference manual. Rome: FAO. 